\title{
Biochemical Observations on Rat Intestine during Chronic Administration of Morphine
}

\author{
Ganesan Vijaiyan Siva, Sorimuthu Subramanian, and \\ Saminathan GOVINDASAMY* \\ Department of Biochemistry, University of Madras, \\ Guindy Campus, Madras 600 025, India
}

(Received August 28, 1995)

\begin{abstract}
Summary Chronic oral intake of morphine sulphate leads to tolerance toward intestinal action and reduced nutritional uptake. The mechanism involved in this tolerance was clarified by studying the levels of intestinal cellular macromolecules and activities of intestinal membrane-bound key enzymes connected with the transport of nutrients. In vivo intestinal absorption of $\left[{ }^{14} \mathrm{C}\right]$ glucose and $\left[{ }^{14} \mathrm{C}\right]$ glycine was examined to study the precise relationship between involvement of enzymes and transport of these labelled nutrients. Male Wistar rats were made morphine dependent. The levels of carbohydrates and glycogen and activities of adenosine triphosphatase, $\mathrm{Na}^{+} \mathrm{K}^{+}$-dependent ATPase, and alkaline phosphatase were decreased in the morphine-treated rats. This altered enzyme activity concurred well with the absorption of labelled nutrients and was reflected in the cellular macromolecular levels of carbohydrates and glycogen. Results from this study indicate that animals develop tolerance through DNA, RNA, and protein synthesis and altered nutritional uptake through defective enzyme machinery, thus explaining the adverse effect of morphine sulphate.
\end{abstract}

Key Words: morphine, narcotic addiction, intestinal transport, tolerance, in vivo absorption

Opiate drugs have various effects on perception of pain, consciousness, motor control, mood, and autonomic function and can induce physical dependence. The endogenous opioid system plays an important role in modulating endocrine, cardiovascular, respiratory, gastrointestinal, and immune functions [1]. The constipating effect of morphine and other opiates and opioids is well known. It is also generally accepted that morphine inhibits the intestinal transit by stimulating

\footnotetext{
* To whom correspondence should be addressed.
} 
nonpropulsive contractions in some species while inhibiting intestinal motility in others [2]. However the precise relationship between intestinal transit and motility is poorly defined [3]. With regard to the gastrointestinal tract, the responses to the repeated administration of morphine are not clear. Tolerance to the effects of morphine on intestinal contractions in vivo appears to develop. On the other hand, results of studies on the development of tolerance to the intestinal actions of morphine in vivo are meager and conflicting [4]. In the present study, therefore, we sought to clarify the mechanism underlying this tolerance by examining the levels of intestinal cell macromolecules as well as the activities of intestinal membranebound key enzymes involved in the transport of nutrients.

\section{MATERIALS AND METHODS}

Male Wistar rats weighing $120-150 \mathrm{~g}$ were addicted to morphine sulphate (Tamilnadu Dadha Pharmaceuticals, India) by oral treatment with morphine sulphate at a dose of $50 \mathrm{mg} / \mathrm{kg}$ body weight given in their drinking water as described by Badawy et al. [5]. Morphine-treated and control animals were allowed access to food and water ad libitum. After 21 days the morphine-treated rats were divided into two groups. In the first group the in vivo absorption of $\left[{ }^{14} \mathrm{C}\right]$ glucose and $\left[{ }^{14} \mathrm{C}\right]$ glycine (Babha Atomic Research Centre, Bombay, India) was assessed by the perfusion technique described by Summers et al. [6]. Experimental and control rats were fasted overnight to reduce intestinal solid matter. The animals were anesthetized by intraperitoneal injection of sodium phenobarbitone $(50 \mathrm{mg} / \mathrm{kg}$ body weight). The abdomen was then opened by a midline incision, and the common bile duct was ligated and an outlet cannula was inserted at the terminal ileum. The entire small intestine was perfused at a constant rate $(0.5 \mathrm{ml} /$ min) with perfusion fluid, containing $135 \mathrm{~mm} \mathrm{NaCl}, 5 \mathrm{~mm}$ unlabelled glucose or glycine, which served as a carrier, and $20 \mu \mathrm{Ci}$ of $\left[{ }^{14} \mathrm{C}\right]$ glucose or $\left[{ }^{14} \mathrm{C}\right]$ glycine per liter. Effluent samples were collected at 10-min intervals for $1 \mathrm{~h}$. A 0.1 -ml volume of effluent solution was mixed with $5.0 \mathrm{ml}$ of scintillation fluid and then taken for the measured for radioactivity in an LKB Pharmacia model liquid scintillation counter. The scintillation fluid was a mixture of dioxane and ethylene glycol (50\% $\mathrm{v} / \mathrm{v}$ ) containing PPO (4.0 g/liter), POPOP (200 mg/liter), and naphthalene $(60 \mathrm{~g} /$ liter). Original radioactivity before perfusion was also measured. The intestinal measurements of absorption were carried out by the method of Lal and Schedl [7].

In the second group, rats were sacrificed by decapitation, after which the intestinal tissue was removed and used for the estimation of membrane-bound enzymes such as total ATPase and $\mathrm{Na}^{+} \mathrm{K}^{+}$-dependent ATPase, assayed by the method of Evans [8], and alkaline phosphatase, by the method of Moog [9]. Cellular levels of macromolecules such as carbohydrates and glycogen [10], protein [11], RNA [12], and DNA [13] were also estimated. The data were statistically analyzed, and Student's $t$-test was used to compare the means of two groups. 


\section{RESULTS}

Figure 1 depicts the in vivo intestinal absorption of $\left[{ }^{14} \mathrm{C}\right]$ glucose and $\left[{ }^{14} \mathrm{C}\right]$ glycine. A gradual increase in the absorption of both radiolabels was observed up to $30 \mathrm{~min}$, followed by a steady decrease in the intestinal absorption, in both control and morphine-treated animals. However, the absorption of these labelled nutrients was less at all times in the treatment group compared with that in the control.

Table 1 shows the intestinal cell levels of macromolecules of the two groups of rats. The carbohydrates and glycogen levels were found to be significantly

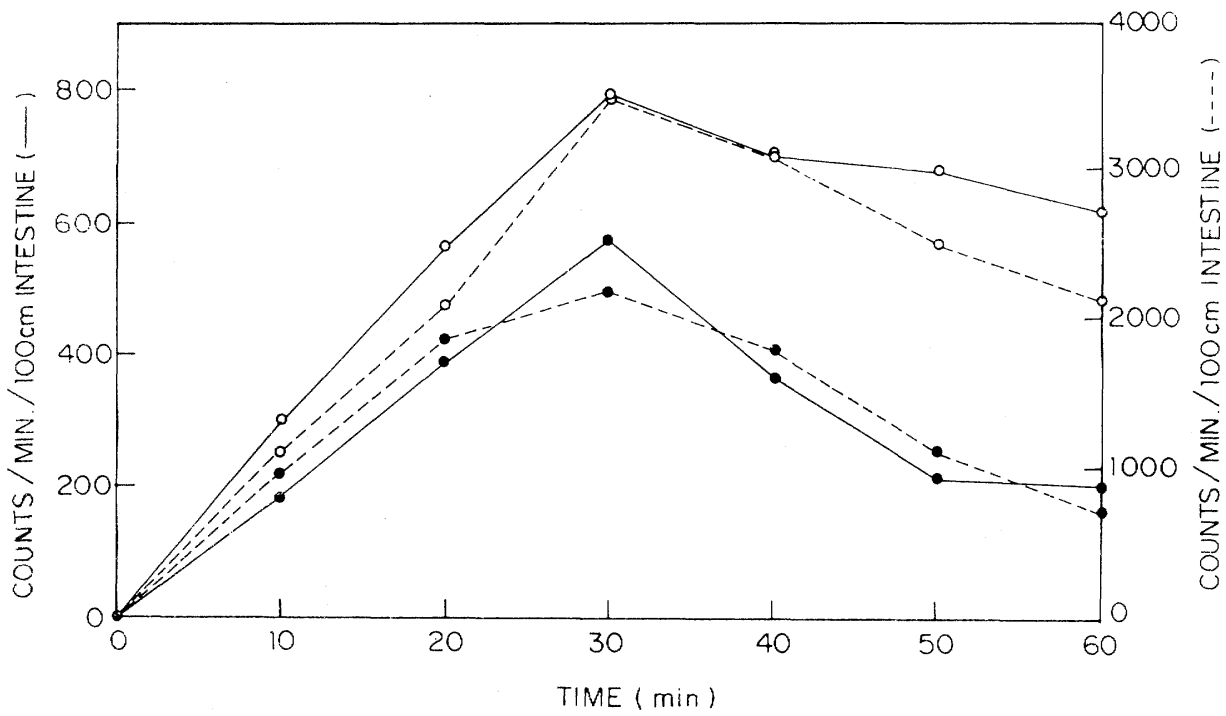

Fig. 1. In vivo absorption of $\left[{ }^{14} \mathrm{C}\right]$ glucose $(--)$ and $\left[{ }^{14} \mathrm{C}\right]$ glycine $(-)$. $\bullet$, morphine administration; $\bigcirc$, control.

Table 1. Cellular macromolecular constituents of intestine in control and morphine sulphate-treated rats.

\begin{tabular}{lcc}
\hline & Normal & Morphine treated \\
& $(\mu \mathrm{g} / \mathrm{g}$ of dried defatted intestine $)$ \\
\hline Alkali-extractable carbohydrates & $14.54 \pm 1.24$ & $11.89 \pm 1.13^{* *}$ \\
Glycogen & $6.72 \pm 0.68$ & $5.56 \pm 0.56^{* *}$ \\
Protein & $133.70 \pm 13.6$ & $162.40 \pm 13.2^{* *}$ \\
DNA & $9.69 \pm 0.28$ & $10.80 \pm 0.47^{* * *}$ \\
RNA & $6.24 \pm 0.28$ & $6.71 \pm 0.18^{* *}$ \\
\hline \multicolumn{1}{l}{ Values are expressed as mean \pm SEM for six animals in each group. $p$ Value: ${ }^{* *} p<0.01}$,
\end{tabular}

$*^{* *} p<0.001$, normal vs. morphine treated rats.

Vol. 20, No. 1, 1996 
Table 2. Activities of membrane-bound enzymes in control and morphine sulphate-treated rats.

\begin{tabular}{lcc}
\hline & Normal & $\begin{array}{c}\text { Morphine treated } \\
(\mu \mathrm{mol} / \mathrm{mg} \text { protein } / \mathrm{h})\end{array}$ \\
\hline Total ATPase & $241.20 \pm 13.80$ & $215.30 \pm 12.70^{* *}$ \\
$\mathrm{Na}^{+} \mathrm{K}^{+}$-dependent ATPase & $85.70 \pm 6.43$ & $73.20 \pm 6.04^{* *}$ \\
$\mathrm{Alkaline}$ phosphatase & $26.50 \pm 5.23$ & $17.60 \pm 4.37^{* *}$ \\
\hline \multicolumn{1}{c}{ Values }
\end{tabular}

Values are expressed as mean \pm SEM for six animals in each group. $p$ Value: ${ }^{* *} p<0.01$, normal vs. morphine-treated rats.

decreased $(p<0.01)$ in the morphine-treated rats when compared with those in the control. In contrast, significant increases were noted in the levels of protein and RNA $(p<0.01)$ and DNA $(p<0.001)$ in the addicted rats. The adverse effect of morphine on rat intestine was further supported by a significant reduction $(p<$ $0.01)$ in the activities of enzymes such as total ATPase, $\mathrm{Na}^{+} \mathrm{K}^{+}$-ATPase, and alkaline phosphatase (Table 2)

\section{DISCUSSION}

The intestinal absorption of nutrients is carrier mediated and energy dependent [14]. Involvement of alkaline phosphatase in the intestinal transport was reported by Rosenberg and Scriver [15] and Riecken et al. [16]. Similarly, Sengupta et al. observed that the inhibition of the ATPase group of enzymes by $\Delta^{9}$-tetrahydro cannabinol in the gastrointestinal tract may result in the defective absorption of dietary materials, thereby leading to a condition of under nutrition [17]. Also, Sekar et al. observed that the administration of codeine decreased the activity of alkaline phosphatase and ATPase [18], which results are in accordance with those of Subramanian et al., who found significant inhibition of carbohydrate and glycogen synthesis during Ochratoxin A toxicosis [19]. Paola et al. demonstrated that morphine-induced reduction in motility was centrally mediated and occurred through involvement of $\mu$-opioid receptors [2]. The enhanced level of protein at the end of 21 days establishes the fact that the development of tolerance to morphine after chronic administration is developed due to synthesis of more protein [20]. Cohen et al. first demonstrated that actinomycin-D, an inhibitor of RNA synthesis, could retard the development of tolerance to morphine in mice and rats [21]. Subsequent studies on inhibitors of protein synthesis, such as cycloheximide, puromycin and mercaptopurine, also showed inhibition of tolerance by these inhibitors [20]. The observed reduction in RNA synthesis on acute treatment and the subsequent enhancement of RNA synthesis on chronic administration of morphine indicate the preliminary RNA inhibition is a transient one. Hence, the chronic treatment causes a shift towards synthesis of a more stable, heavier RNA. Similarly, enhanced in vivo DNA synthesis of neonatal brain cells during morphine administration was noticed by Kornblum et al. [22]. A decrease 
in the specific activity of DNase and RNase during chronic morphine treatment was suggested to cause the increased content of DNA and RNA [23]. Hence it may be inferred that the tolerance developed is nothing but the consequence of the action of a defense mechanism against morphine involving the activation of replication, transcription, and protein synthesis. The main observation to be stressed at this juncture is that the chronic administration of morphine affects intestinal enzyme machinery, thereby decreasing the absorption of glucose and glycine. On the other hand, development of tolerance is inevitable during chronic morphine administration which is due to the enhanced synthesis of protein, DNA, and RNA. From the above observations, we conclude that morphine sulphate, a narcotic analgesic, exerts its constipating effect by inhibiting the intestinal transit via inhibition of the enzyme machinery and exerts tolerance through enhanced protein, RNA, and DNA synthesis.

The author G.V. thanks Defence Research and Development Organisation (DRDO), Government of India, for financial assistance in the form of a Senior Research Fellowship.

\section{REFERENCES}

1. Yasuda, K., Raynor, K., Kong, H., Breder, C.D., Takeda, J., Reisine, T., and Bell, G.I. (1993): Cloning and functional comparison of $\varkappa$ and opioid receptors from mouse brain. Proc. Natl. Acad. Sci., U.S.A., 90, 6736-6740.

2. Paola, M., Gingnoni, N., Basilico, L., Gori, E., Rubino, T., and Parolaro, D. (1994): Intestinal effect of morphine-6-glucuronide. In vivo and in vitro characterisation. Eur. $J$. Pharmacol., 253, 269-274.

3. Galligan, J.J., and Burks, T.F. (1983): Centrally mediated inhibition of small intestinal transit and motility by morphine in the rat. J. Pharmacol. Exp. Ther., 226, 356-361.

4. Weisbrodt, N.W., Aceves, F.B., Dudrick, S.J., Burks, T.F., and Castro, G.A. (1977): Tolerance to the effect of morphine on intestinal transit. Proc. Soc. Exp. Biol. Med., 154, $587-590$.

5. Badawy, A.A.B., Evans, C.M., and Evans, M. (1982): Production of tolerance and physical dependence in the rat by simple administration of morphine in drinking water. $B r . J$. Pharmacol., 75, 485-491.

6. Summers, R.W., Ken, T.H., and Osborne, J.W. (1970): Effects of drugs, obstruction and irradiation on rat gastrointestinal propulsion. Gastroenterology, 59, 731-739.

7. Lal, D., and Sched1, H.P. (1974): Intestinal adaptation in diabetes: Amino acid absorption. Am. J. Physiol., 227, 827-831.

8. Evans, D.J., Jr. (1969): Membrane adenosine triphosphatase of Escherichia coli: Activation by calcium ion and inhibition by monovalent cations. J. Bacteriol., 100, 914-922.

9. Moog, F. (1946): Alkaline and acid phosphomonoesterase activity in chick embryos. J. Cell. Comp. Physiol, 28, 197-208.

10. Morales, M.A., Jabbagy, A.J., and Tarenzi, H.P. (1973): Mutations affecting accumulation of glycogen. Neurospora Newsl., 20, 24-25.

11. Lowry, O.H., Rosebrough, N.J., Farr, A.L., and Randall, R.J. (1951): Protein measurement with the Folin-Phenol reagent. J. Biol. Chem., 193, 265-275.

12. Schmidt, G. (1957): Preparation of ribonucleic acid from yeast and animal tissues, in Methods in Enzymology, Vol. III, Sec. V, Nucleic Acids and Derivatives, ed. by Colowick, S.P., and Kaplan, N.O., Academic Press, New York, pp. 687-691.

13. Burton, K. (1956): The conditions and mechanisms of the diphenylamine reaction for the 
colorimetric estimation of deoxyribonucleic acid. Biochem. J., 62, 315-323.

14. Curran, P.F., Stanley, G., Schultz, S.G., Chez, R.A., and Fuisz, R.E. (1967): Kinetic relations of the Na-aminoacid interaction at the mucosal border of intestine. J. Gen. Physiol., 50, 1261-1286.

15. Rosenberg, L.E., and Scriver, C.R. (1974): Disorders of amino acid metabolism, in Duncan's Diseases of Metabolism, 7 th ed., ed. by Bondy, P.K., and Rosenberg, L.E., W.B. Saunders Co., Tokyo, pp. 465-475.

16. Riecken, E.O., Lorenz, M.H., Sachlfeld, M., and Block, R. (1976): Intestinal ion transport, in Proceedings of International Symposium 1975 (Pub 1976), ed. by Robinson, J.W.L., University Park Press, Baltimore, Maryland, pp. 371-375.

17. Sengupta, D., Indira, C., Datta, S.C., and Ghosh, J.J. (1976): Effect of $\Delta^{9}$-tetrahydrocannabinol on rat intestinal ATPases. Indian J. Biochem. Biophys., 14, 93-94.

18. Sekar, N., William, S., and Govindasamy, S. (1986): Effect of codeine on rat intestine. Curr. Sci., 55, 1024-1026.

19. Subramanian, S., Balasubramanian, S., William, S., and Govindasamy, S. (1991): In vivo absorption of ${ }^{14} \mathrm{C}$-glucose and ${ }^{14} \mathrm{C}$-glycine by the rat intestine during Ochratoxin $\mathrm{A}$. Toxicosis. Biochem. Int., 23, 655-661.

20. Cox, B.M., and Osman, O.H. (1970): Inhibition of development of tolerance to morphine in rats by drugs which inhibit ribonucleic acid and protein synthesis. Br. J. Pharmacol, 38 , $157-170$.

21. Cohen, M., Keats, A.S., Krivoy, W., and Ungar, G. (1965): Effect of actinomycin-D on morphine tolerance. Proc. Soc. Exp. Biol. Med., 119, 381-384.

22. Kornblum, H.I., Loughlin, S.E., and Leslie, F.M. (1987): Effects of morphine on DNA synthesis in neonatal rat brain. Dev. Brain Res., 31, 45-52.

23. Datta, R.K., and Antopol, W. (1972): Inhibitory effects of chronic administration of morphine on uridine and thymidine incorporating abilities of mouse liver and brain subcellular fractions. Toxicol. Appl. Pharmacol., 23, 75-81. 